\title{
Effects of Mycorrhizal Fungi with Phosphate Fertilizer Applications on Phosphate Solubilizing and Soil Properties of Grapes Orchard
}

\author{
Saifon Tiamtanong ${ }^{1}$, Kanokkorn Sinma ${ }^{1}$, Thongchai Mala ${ }^{1}$, Pornpairin Rungcharoenthong ${ }^{2} \&$ Suphachai \\ Amkha $^{1}$ \\ ${ }^{1}$ Department of Soil Science, Faculty of Agriculture at KamphaengSaen, Kasetsart University, Nakhon Pathom, \\ Thailand \\ ${ }^{2}$ Department of Science, Botany, Faculty of Liberal Arts and Science, Kasetsart University, Nakhon Pathom, \\ Thailand \\ Correspondence: Suphachai Amkha, Department of Soil Science, Faculty of Agriculture at KamphaengSaen, \\ Kasetsart University, Nakhon Pathom 73140, Thailand. E-mail: agrscak@ku.ac.th
}

Received: August 12, 2014

Accepted: August 17, $2014 \quad$ Online Published: December 10, 2014

doi:10.5539/mas.v9n1p149

URL: http://dx.doi.org/10.5539/mas.v9n1p149

\begin{abstract}
The objective of this study was to efficiency determined of mycorrhizal fungi with different phosphate fertilizer application on phosphate solubilizing and soil properties of grapes orchard. The treatments were arranged in $2 \times 5$ factorials in Randomized Complete Block Design (RCBD) with 5 replications. Factor 1: two levels of mycorrhizal fungi were non-inoculation and inoculation. Factor 2: five levels of phosphate fertilizer application were $0,27.17,54.34,81.52$ and $108.69 \mathrm{~g} \mathrm{plant}^{-1}$ by soil analysis recommendation. The collected data was spore number, root colonization density, phosphatases activity of mycorrhizal fungi, available phosphorus (P) in soil, soil $\mathrm{pH}$ and phosphorus in leaf. The results showed that the inoculation of mycorrhizal fungi increased spore number, root colonization density, phosphatases activity of mycorrhizal fungi, available $\mathrm{P}$ in soil and $\mathrm{P}$ in leaf compared with the non-inoculated. While, phosphate fertilizer at a rate $54.34 \mathrm{~g} \mathrm{plant}^{-1}$ increased spore number, root colonization density, phosphatases activity of mycorrhizal fungi, available $\mathrm{P}$ in soil and $\mathrm{P}$ in leaf. Mycorrhizal fungi combination with $54.34 \mathrm{~g} \mathrm{plant}^{-1}$ of phosphate fertilizer increased spore number, root colonization density, phosphatases activity and available $\mathrm{P}$ in soil.
\end{abstract}

Keywords: fertilizer, grape, mycorrhizal fungi, phosphate

\section{Introduction}

Grape has been planted commercially in several areas at Nakhonratchasrima Province. Currently, varieties that encourage farmers planting was Beauty Seedless, a seedless of grapes varieties with circular shaped, black berries and the fruit size about $1 \mathrm{~cm}$. Chemical fertilizer was used to provide nutrient at a high rate for a long time. This has resulted in pollution, decreased biodiversity in intensively-farmed regions, and environmental degradation linked to use of chemical inputs is increasingly widespread and sometimes irreversible. Beneficial microorganisms, including $\mathrm{N}_{2}$-fixing bacteria and arbuscular mycorrhizal (AM) fungi, provide minerals to plants and directly implicated in crop production (Plenchette et al., 2005). The plant receives many benefits from this relation, including enhanced uptake of poorly mobile soil nutrients and reduced susceptibility of roots to soil-borne pathogens (Quilambo, 2003) and also in area for growing grapes have strongly acidic soils. Which low pH with aluminum (Al) toxicity, high phosphorus (P) fixation, low levels of soil organic matter, and a loss of soil biodiversity (Irene \& Thomas 2006). The ability of AM fungi to enhance host plant uptake of relatively immobile nutrients, in particular P, and several micronutrients, has been the most recognized beneficial effect of mycorrhiza, by increasing the area of the more absorbing. Hyphae that live on plants to expand its territory to find food even more, including roots, root has a surface area than normal. Mycorrhizal fungi can promote the growth of other microorganisms for phosphate solubilizers around plant roots. The soluble phosphate is released then fungi and roots also were benefits (Plenchette et al., 2005). Though plants require adequate phosphorus (P) in the early stages of growth for optimum crop production (Grant et al., 2001), excess P supply in the soil is a major environmental concern (Plenchette et al., 2005). Moreover the reserves of $\mathrm{P}$ in the world are finite and are gradually being depleted (Tiessen, 1995). Thus there is need to develop agricultural systems based on meeting minimum $\mathrm{P}$ requirements for crops. The effectiveness of AM on phosphate solubilization, plant growth and $\mathrm{P}$ 
uptake are evaluated.

\section{Materials and Methods}

The experiment was conducted in Wangnamkhiao District, Nakhonratchasima Province, Thailand. Soil samples from the experimental site were analyzed at Soil Science Department, Faculty of Agriculture, Kasetsart University, Kamphangsaen Campus, Thailand. The soil was composed of sandy loam texture, a low amount of organic matter content $(1.19 \%)$, a low amount of exchangeable phosphorus $\left(27.13 \mathrm{mg} \mathrm{kg}^{-1}\right)$, a low amount of available phosphorus $\left(8.81 \mathrm{mg} \mathrm{kg}^{-1}\right)$ with $\mathrm{pH} 6.8$ and electrical conductivity $\left(0.36 \mathrm{ds} \mathrm{m}^{-1}\right)$ was not salty. The previous crop on the experimental site was grapes.

For each experiment, $2 \times 5$ factorial in RCBD with 5 replications was developed. Factor 1 , Mycorrhizal fungi were non-inoculation and inoculation $300 \mathrm{~g} \mathrm{plant}^{-1}$. Factor 2, Phosphate fertilizer were 0, 28.17, 54.34, 81.52 and $108.69 \mathrm{~g} \mathrm{plant}^{-1}$. Each factor size was $3 \mathrm{~m}$ wide and $3 \mathrm{~m}$ long which each size was composed of two rows of grapes planted during the wet season in July to October 2013.

\section{Preparation of Mycorrhizal fungi inoculums}

The inoculum of Mycorrhizal fungi, Glomus aggregatum was produced in sterilized Nam Phong soil using maize as host plant. The inoculum production in this experiment was prepared as described by Mala (1998). The host plant, sorghum, had been grown for 13 weeks. After harvest the inoculum, the amount of spore in each species was checked. The inoculum with the number of spore above 50 spore $\mathrm{g}^{-1}$ was selected for further experiment

\section{Mycorrhizal fungi inoculation and planting}

Conduct experiments according to prescribed treatments. Inoculation treatments by around sprinkling the grapes tree at pruning period. Use the shovel to dig soil around landfills each species and the drip irrigation. For the basal fertilizer application, $62.2 \mathrm{~kg} \mathrm{ha}^{-1} \mathrm{~N}$ of urea $(46 \% \mathrm{~N})$ and $74.67 \mathrm{~kg} \mathrm{ha}^{-1} \mathrm{~K}_{2} \mathrm{O}$ as potassium chloride $\left(60 \% \mathrm{~K}_{2} \mathrm{O}\right)$ and as triple superphosphate $\left(46 \% \mathrm{P}_{2} \mathrm{O}_{5}\right)$ and were applied in all factor.

\section{Data collection}

The soil was sampled at flowering stage, fruit setting stage and after harvest for soil properties analysis. By soil properties were available phosphorus and soil reaction $(\mathrm{pH})$ at a depth of $0-30 \mathrm{~cm}$ including leaf $\mathrm{P}$ concentration. The harvesting root infection percentage, spore and enzyme phosphates in soil were collected at flowering stage and fruit setting stage. Soil samples were analyzed, spore were evaluated by the wet sieving method )Brundrett et al. 1994( and the mycorrhizal root infection percentages were evaluated by Gridline Intersect Method (Giovanetti \& Mosse, 1980) and enzyme phosphatase were evaluated by colorimetric assay method )Tabatabai and Bremner, 1969(. Available P was measured colorimetrically with a spectrophotometer using Bray II method (Bray \& Kurtz, 1945). P of plant was determined by Vanado-molybdate method described by Tassanee et al. (1989). The soil reaction $(\mathrm{pH})$ was measured with $\mathrm{pH}$ meter by $1: 1$ soil solution in $\mathrm{H}_{2} \mathrm{O}$ and $1 \mathrm{M} \mathrm{KCl}$ (Peech, 1965).

\section{Statistical analysis}

The variance of every parameter was analyzed. Then, the relevant average means were compared by LSD at $95 \%$ and $99 \%$ confidence. Analysis of variance was used to determine effects of AM fungal inoculation on soil properties using the R program version R-2.10.1-win32.

\section{Results}

\subsection{The Effect of Mycorrhizal Fungi and Phosphate Fertilizer on Soil Microbial Properties in Grape Orchard at Growth Stages}

\subsubsection{Spore Number}

Analysis of the inoculation indicated that spore number was significantly different at flowering stage and fruit setting (Table 1). The maximum intensity of spore number was observed in treatments of inoculation at flowering stage showed that non-inoculation and inoculation treatments affected a spore number in soil with a spore number accumulation of 32.80 spore numbers per $10 \mathrm{~g}$ soil. Inoculation treatment had greater spore number more than non-inoculation which produced the lowest spore number (1.0 spore number per $10 \mathrm{~g}$ soil). Which, Phosphate fertilizer application at a rate $27.17 \mathrm{~g}$ plant $^{-1}$ was gave the highest of spore number than others phosphate fertilizer applications. While, the maximum intensity of spore number was observed in treatments of inoculation at fruit setting stage showed that inoculation treatments affected a spore number in soil with a spore number accumulation of 33.20 spore numbers per $10 \mathrm{~g}$ soil. Inoculation treatment had greater spore number than non-inoculation which produced the lowest spore number (1.60 spore number per $10 \mathrm{~g}$ soil). Phosphate fertilizer 
application gave more spore number $27.17 \mathrm{~g}$ plant $^{-1}$ applications than the others and the maximum intensity of spore number was 23.50 spore numbers per $10 \mathrm{~g}$ soil.

Table 1. Mycorrhizal fungi on spore number in soil at flowering and fruit setting stage of grape (spore number per $10 \mathrm{~g}$ soil)

\begin{tabular}{|c|c|c|c|c|c|c|}
\hline \multirow[b]{2}{*}{ Fertilizers (F) } & \multicolumn{2}{|c|}{ Flowering stage } & \multirow{2}{*}{$\begin{array}{l}\text { Average } \\
\text { (M) }\end{array}$} & \multicolumn{2}{|c|}{ Fruit setting stage } & \multirow{2}{*}{$\begin{array}{l}\text { Average } \\
\text { (M) }\end{array}$} \\
\hline & $\begin{array}{c}\text { Non-inoculation } \\
\text { (M1) }\end{array}$ & $\begin{array}{c}\text { Inoculation } \\
\text { (M2) }\end{array}$ & & $\begin{array}{c}\text { Non-inoculation } \\
\text { (M1) }\end{array}$ & $\begin{array}{c}\text { Inoculation } \\
\text { (M2) }\end{array}$ & \\
\hline 0 g plant $^{-1}$ & $0.00 \mathrm{~d}$ & $27.00 \mathrm{c}$ & $13.50 \mathrm{D}$ & $0.00 \mathrm{~d}$ & $31.00 \mathrm{c}$ & $15.50 \mathrm{C}$ \\
\hline 27.17 g plant $^{-1}$ & $1.00 \mathrm{~d}$ & $38.00 \mathrm{a}$ & $19.50 \mathrm{~A}$ & $0.00 \mathrm{~d}$ & $47.00 \mathrm{a}$ & $23.50 \mathrm{~A}$ \\
\hline $54.34 \mathrm{~g}$ plant $^{-1}$ & $2.00 \mathrm{~d}$ & $33.00 \mathrm{~b}$ & $17.50 \mathrm{~B}$ & $1.00 \mathrm{~d}$ & $36.00 \mathrm{~b}$ & $18.50 \mathrm{~B}$ \\
\hline $81.52 \mathrm{~g}$ plant $^{-1}$ & $1.00 \mathrm{~d}$ & $32.00 \mathrm{~b}$ & $17.50 \mathrm{~B}$ & $3.00 \mathrm{~d}$ & $27.00 \mathrm{c}$ & $15.00 \mathrm{C}$ \\
\hline $108.69 \mathrm{~g} \mathrm{plant}^{-1}$ & $1.00 \mathrm{~d}$ & $32.00 \mathrm{~b}$ & $16.50 \mathrm{C}$ & $4.00 \mathrm{~d}$ & $25.00 \mathrm{c}$ & $14.50 \mathrm{C}$ \\
\hline Average (F) & $1.00 \mathrm{~B}$ & $32.8 \mathrm{~A}$ & & $1.60 \mathrm{~B}$ & $33.20 \mathrm{~A}$ & \\
\hline F-test ; F & & ** & & & $* *$ & \\
\hline $\mathrm{M}$ & & ** & & & ** & \\
\hline $\mathrm{F} * \mathrm{M}$ & & ** & & & ** & \\
\hline C.V. (\%) & & 11.81 & & & 12.23 & \\
\hline
\end{tabular}

Note. Number is average of 4 replications, followed by a letter. Different letter means a significant different at $99 \%$ confidence interval by LSD.

\subsubsection{Root Colonization}

There was a significant variation in root colonization by the different phosphate fertilizer tested. Phosphate fertilizer application and inoculation were found to be significantly superior to others at flowering stage and fruit setting stage after inoculation (Table 2). The maximum intensity of root colonization was observed in treatments of inoculation, which non-inoculation and inoculation treatments affected root colonization, with root colonization accumulation of $38.71 \%$. Inoculation treatment had greater root colonization than non-inoculation which produced the lowest spore number $(2.07 \%)$. However, further inspection showed that phosphate fertilizer application (54.34 $\mathrm{g}$ plant $\left.^{-1}\right)$ find root colonization more than others at flowering stage. This, the maximum intensity of root colonization was $16.13 \%$. Inoculation treatments were affected root colonization with root colonization accumulation of $26.92 \%$. Inoculation treatment had greater root colonization more than the treatment of non-inoculation which produced the lowest root colonization $(1.03 \%)$. However, further inspection showed that phosphate fertilizer application $\left(54.34 \mathrm{~g} \mathrm{plant}^{-1}\right)$ find root colonization more than others at fruit setting stage. This, the maximum intensity of root colonization was $16.13 \%$.

Table 2. Mycorrhizal fungi on root colonization (\%) at flowering and fruit setting stage of grape

\begin{tabular}{|c|c|c|c|c|c|c|}
\hline \multirow[b]{2}{*}{ Fertilizers (F) } & \multicolumn{2}{|c|}{ Flowering stage } & \multirow{2}{*}{$\begin{array}{l}\text { Average } \\
\text { (M) }\end{array}$} & \multicolumn{2}{|c|}{ Fruit setting stage } & \multirow{2}{*}{$\begin{array}{l}\text { Average } \\
\text { (M) }\end{array}$} \\
\hline & $\begin{array}{c}\text { Non-inoculation } \\
\text { (M1) }\end{array}$ & $\begin{array}{l}\text { Inoculation } \\
\text { (M2) }\end{array}$ & & $\begin{array}{c}\text { Non-inoculation } \\
\text { (M1) }\end{array}$ & $\begin{array}{c}\text { Inoculation } \\
\text { (M2) }\end{array}$ & \\
\hline 0 g plant $^{-1}$ & $0.00 \mathrm{c}$ & $33.33 b$ & $16.67 \mathrm{D}$ & $0.00 \mathrm{~d}$ & $28.13 \mathrm{ab}$ & $14.06 \mathrm{~B}$ \\
\hline 27.17 g plant $^{-1}$ & $0.00 \mathrm{c}$ & $43.33 \mathrm{a}$ & 21.67B & $0.00 \mathrm{~d}$ & $25.81 \mathrm{~b}$ & $12.51 \mathrm{C}$ \\
\hline $54.34 \mathrm{~g}$ plant $^{-1}$ & $2.70 \mathrm{c}$ & $44.74 \mathrm{a}$ & $23.72 \mathrm{~A}$ & $0.00 \mathrm{~d}$ & $32.26 \mathrm{a}$ & $16.13 \mathrm{~A}$ \\
\hline $81.52 \mathrm{~g} \mathrm{plant}^{-1}$ & $2.38 \mathrm{c}$ & $35.00 \mathrm{~b}$ & $18.69 \mathrm{C}$ & $2.38 \mathrm{~d}$ & $26.19 b$ & $14.88 \mathrm{~B}$ \\
\hline 108.69 g plant $^{-1}$ & $5.26 \mathrm{c}$ & $37.14 \mathrm{~b}$ & $21.20 \mathrm{~B}$ & $2.78 \mathrm{~d}$ & $22.22 \mathrm{c}$ & $12.50 \mathrm{C}$ \\
\hline Average (F) & $2.07 \mathrm{~B}$ & $38.71 \mathrm{~A}$ & & $1.03 \mathrm{~B}$ & $26.92 \mathrm{~A}$ & \\
\hline F-test ; F & & $* *$ & & & $* *$ & \\
\hline M & & ** & & & $* *$ & \\
\hline $\mathrm{F}^{*} \mathrm{M}$ & & ** & & & $* *$ & \\
\hline C.V. (\%) & & 12.36 & & & 12.61 & \\
\hline
\end{tabular}

Note. Number is average of 4 replications, followed by a letter. Different letter means a significant different at $99 \%$ confidence interval by LSD. 


\subsubsection{Phosphatase Activity in Soil}

Our experimental results demonstrated that phosphatase activity in soil at flowering stage and fruit setting stage were shown in Table 3. The quantity of phosphatase activity in soil each phosphate fertilizer application was significantly different at the $99 \%$ confidence level, which in the mycorrhizal fungi treatments was significantly different at the $99 \%$ confidence level. The maximum intensity of phosphatase activity in soil was observed in treatments of inoculation, non-inoculation and inoculation treatments affected phosphatase activity in soil, with phosphatase activity in soil accumulation of 1.27 unit of $\mu \mathrm{mol} \mathrm{PNP} / \mathrm{g}$ soil/hours. Inoculation treatment had greater phosphatase activity in soil than treatment of non-inoculation which produced the lowest phosphatase activity in soil ( 0.83 unit of $\mu \mathrm{mol} \mathrm{PNP} / \mathrm{g}$ soil/hours). However, further inspection showed that phosphate fertilizer application (54.34 $\left.\mathrm{g} \mathrm{plant}^{-1}\right)$ find phosphatase activity in soil more than others which was 1.18 unit of $\mu \mathrm{mol} \mathrm{PNP} / \mathrm{g}$ soil/hours at flowering stage. The maximum intensity of phosphatase activity in soil was observed in treatments of inoculation, non-inoculation and inoculation treatments affected phosphatase activity in soil, with phosphatase activity in soil accumulation of 1.80 unit of $\mu \mathrm{mol} \mathrm{PNP} / \mathrm{g}$ soil/hours. Inoculation treatment had greater phosphatase activity in soil more than the treatment of non-inoculation which produced the lowest phosphatase activity in soil (1.21 unit of $\mu \mathrm{mol} \mathrm{PNP} / \mathrm{g}$ soil/hours). However, further inspection showed that phosphate fertilizer application $\left(27.17,54.34\right.$ and $\left.81.52 \mathrm{~g} \mathrm{plant}^{-1}\right)$ find phosphatase activity in soil more than other another was $1.59,1.56$ and 1.58 unit of $\mu \mathrm{mol} \mathrm{PNP} / \mathrm{g}$ soil/hours respectively.

Table 3. Mycorrhizal fungi on phosphatase activity (unit of $\mu \mathrm{mol} \mathrm{PNP} / \mathrm{g}$ soil/hours) in soil at flowering and fruit setting stage of grape

\begin{tabular}{|c|c|c|c|c|c|c|}
\hline \multirow[b]{2}{*}{ Fertilizers (F) } & \multicolumn{2}{|c|}{ Flowering stage } & \multirow{2}{*}{$\begin{array}{l}\text { Average } \\
\text { (M) }\end{array}$} & \multicolumn{2}{|c|}{ Fruit setting stage } & \multirow{2}{*}{$\begin{array}{l}\text { Average } \\
\text { (M) }\end{array}$} \\
\hline & $\begin{array}{c}\text { Non-inoculation } \\
\text { (M1) }\end{array}$ & $\begin{array}{l}\text { Inoculation } \\
\text { (M2) }\end{array}$ & & $\begin{array}{c}\text { Non-inoculation } \\
\text { (M1) }\end{array}$ & $\begin{array}{c}\text { Inoculation } \\
\text { (M2) }\end{array}$ & \\
\hline $0 \mathrm{~g} \mathrm{plant}^{-1}$ & $0.72 \mathrm{f}$ & $1.39 \mathrm{ab}$ & $1.05 \mathrm{~B}$ & $1.24 \mathrm{ef}$ & $1.47 \mathrm{~d}$ & $1.35 \mathrm{C}$ \\
\hline $27.17 \mathrm{~g} \mathrm{plant}^{-1}$ & $0.85 \mathrm{e}$ & $1.21 \mathrm{~b}$ & $1.03 \mathrm{~B}$ & $1.23 \mathrm{ef}$ & $1.95 \mathrm{~b}$ & $1.59 \mathrm{~A}$ \\
\hline $54.34 \mathrm{~g} \mathrm{plant}^{-1}$ & $0.94 \mathrm{~d}$ & $1.43 \mathrm{a}$ & $1.18 \mathrm{~A}$ & $1.06 \mathrm{f}$ & $2.04 \mathrm{a}$ & $1.56 \mathrm{~A}$ \\
\hline $81.52 \mathrm{~g} \mathrm{plant}^{-1}$ & $0.86 \mathrm{e}$ & $1.20 \mathrm{~b}$ & $1.03 \mathrm{~B}$ & $1.19 \mathrm{ef}$ & $1.96 \mathrm{~b}$ & $1.58 \mathrm{~A}$ \\
\hline 108.69 g plant $^{-1}$ & $0.92 \mathrm{~d}$ & $1.15 \mathrm{c}$ & $0.97 \mathrm{C}$ & $1.31 \mathrm{e}$ & $1.59 \mathrm{c}$ & $1.46 \mathrm{~B}$ \\
\hline Average (F) & $0.83 \mathrm{~B}$ & $1.27 \mathrm{~A}$ & & $1.21 \mathrm{~B}$ & $1.80 \mathrm{~A}$ & \\
\hline F-test ; F & & $* *$ & & & $* *$ & \\
\hline M & & $* *$ & & & $* *$ & \\
\hline $\mathrm{F}^{*} \mathrm{M}$ & & ** & & & $* *$ & \\
\hline C.V. (\%) & & 11.61 & & & 8.46 & \\
\hline
\end{tabular}

Note. Number is average of 4 replications, followed by a letter. Different letter means a significant different at $99 \%$ confidence interval by LSD.

\subsection{The Effect of Mycorrhizal Fungi and Phosphate Fertilizer on Chemical Properties in Grape Orchard at Different Growth Stages}

\subsubsection{Available P in Soil}

Our experimental results demonstrated that available $\mathrm{P}$ in the soil at flowering stage, fruit setting stage and after harvested were shown in Table 4 . The quantity of soil available $\mathrm{P}$ in each treatment was significantly different at the $99 \%$ confidence level. The non-inoculation and inoculation treatments affected the available $\mathrm{P}$ in soil. By the time, inoculation treatment was released and gave the highest of available $\mathrm{P}$ in soil than non-inoculation treatment at all growth stages. While, the different of phosphate fertilizers application rates gave the significantly different available $\mathrm{P}$ in soil all the growth stages. The available $\mathrm{P}$ in soil was highest when phosphate fertilizer application at a rate $54.34 \mathrm{~g} \mathrm{plant}^{-1}$. However, the available $\mathrm{P}$ in soil was highest in flowering stage and then tent to decrease until harvested stage.

\subsubsection{Soil Reaction $(\mathrm{PH})$}

Analytical data at flowering stage, fruit setting stage and after harvest showed that $\mathrm{pH}$ of soil in each treatment was significantly different at the $99 \%$ confidence level (Table 5). The non-inoculation and inoculation treatments affected the soil $\mathrm{pH}$ by the time, inoculation treatment was gave the soil $\mathrm{pH}$ lower than non-inoculation treatment all the growth stages. While, the different of phosphate fertilizers application rates gave the significantly different soil $\mathrm{pH}$ all the growth stages. The soil $\mathrm{pH}$ value tent to decrease when the phosphate fertilizer 
application was increased the application rate.

\subsubsection{Leaf P Concentration}

The leaf $\mathrm{P}$ concentrations at flowering stage, fruit setting stage and after harvested were shown in Table 6 . The leaf $\mathrm{P}$ concentration was significantly different at the $99 \%$ confidence level. The non-inoculation and inoculation treatments affected the leaf $\mathrm{P}$ concentration that inoculation treatment had greater leaf $\mathrm{P}$ concentration than non-inoculation all the growth stages. The leaf $\mathrm{P}$ concentration of flowering stage was higher than harvesting stage. While, the different of phosphate fertilizers application rates gave the significantly different leaf $\mathrm{P}$ concentration all the growth stages. The data revealed that the leaf P concentration at flowering stage was maximized in phosphate fertilizer application at a rate $27.17 \mathrm{~g} \mathrm{plant}^{-1}$.

\section{Discussion}

The results showed that, at flowering stage and fruit setting stage of phosphate fertilizer application at a rate $27.17 \mathrm{~g} \mathrm{plant}^{-1}$ increased spore number more than other treatments due to the spore number also varied with different treatments. It was found that in high concentration of fertilizer, the AM spore number as well as root colonization decreased, which was in accordance with the findings of Aguilera-Gomez et al. (1999) and Linderman \& Davis (2004). Although, number spores the most found when phosphate fertilizer application (27.17 $\left.\mathrm{g} \mathrm{plant}^{-1}\right)$, but root colonization in phosphate fertilizer application $\left(54.34 \mathrm{~g} \mathrm{plant}^{-1}\right)$ was found root colonization more than other treatments due to higher sporulation and root colonization helps increase fungal host contact and the exchange of nutrients Several earlier reports also noted the positive influence of AMF along with rhizobacteria on AM root colonization (Gamalero et al., 2004; Das et al., 2007). In addition to changes in the mycorrhization of soil, there were also changes in the functioning of the systems, as evaluated by measuring the soil enzyme activity. The measurement of the phosphatase activity provided a good index of mycorrhizal effect on nutrient uptake, especially phosphorus. In experiments was found that, Phosphate fertilizer application $\left(54.34 \mathrm{~g} \mathrm{plant}^{-1}\right)$ was high root colonization as a result mycorrhizal fungi produce enzyme phosphatase when over time. The increased phosphatase activity found in the mycorrhizal roots indicated an increase in the $\mathrm{P}$ content. The ability of mycorrhizae to produce phosphatase enzymes actually depends upon the availability of phosphorus in the soil. In the $\mathrm{P}$ cycle, enzyme activities are inversely related to $\mathrm{P}$ availability (Tadano et al., 1993). According to Sumana (1998) and Kumar et al. (2008), the acid phosphatase activity actually increases with increased root colonization by AM fungi. Those treatments which decrease the available phosphate cause an overall increase in the phosphatase activity (Azcón \& Barea, 1997). Then, low phosphorus availability, P demand increases that resulting increase the phosphatase activity. It was found at the AM-colonized roots in this experiment.

Which, Alacón et al. (2002) reported that plants need phosphorus during growth and productivity when colonization of root by fungus used phosphorus as a carbon source for the needs of the plant. Thus, AM stimulated to create a RAPA (root acid phosphatase activity) increased the presence of phosphorus limited for growth. While, the different phosphate fertilizer application rates gave the different available $\mathrm{P}$ in soil at the each growth stage that the plant beneficial to nutrient uptake needs nutrients unequal during certain times of the growth. (Barker and Pilbeam, 2007) and may be affected of the soil pH (Irene \& Thomas, 2006).

In addition to changes in the mycorrhization of soil, there were also changes in the functioning of the systems, as evaluated by measuring the soil enzyme activity. The measurement of the phosphatase activity provided a good index of mycorrhizal effect on nutrient uptake, especially phosphorus. The experiments found that phosphate fertilizer application at a rate $54.34 \mathrm{~g}_{\text {plant }}{ }^{-1}$ gave high root colonization as same as a result mycorrhizal fungi produce enzyme phosphatase. The increased phosphatase activity found in the mycorrhizal roots indicated an increase in the $\mathrm{P}$ content. The ability of mycorrhizae to produce phosphatase enzymes actually depends upon the availability of $\mathrm{P}$ in the soil. In the $\mathrm{P}$ cycle, enzyme activities are inversely related to $\mathrm{P}$ availability (Tadano et al., 1993). According to Sumana (1998) and Kumar et al. (2008), the acid phosphatase activity actually increases with increased root colonization by AM fungi. Those treatments which decrease the available phosphate cause an overall increase in the phosphatase activity (Azcón \& Barea, 1997). 
Table 4. Available phosphorus content $\left(\mathrm{mg} \mathrm{kg}^{-1}\right)$ in soil at flowering, fruit setting and harvesting stage of grape

\begin{tabular}{|c|c|c|c|c|c|c|c|c|c|}
\hline \multirow[b]{2}{*}{ Fertilizers (F) } & \multicolumn{2}{|c|}{ Flowering stage } & \multirow{2}{*}{$\begin{array}{c}\text { Average } \\
\text { (M) }\end{array}$} & \multicolumn{2}{|c|}{ Fruit setting stage } & \multirow{2}{*}{$\begin{array}{c}\text { Average } \\
\text { (M) }\end{array}$} & \multicolumn{2}{|c|}{ Harvesting stage } & \multirow{2}{*}{$\begin{array}{c}\text { Average } \\
\text { (M) }\end{array}$} \\
\hline & $\begin{array}{c}\text { Non- } \\
\text { inoculation } \\
\text { (M1) }\end{array}$ & $\begin{array}{c}\text { Inoculation } \\
\text { (M2) }\end{array}$ & & $\begin{array}{c}\text { Non- } \\
\text { Inoculation } \\
\text { (M1) }\end{array}$ & $\begin{array}{l}\text { Inoculation } \\
\text { (M2) }\end{array}$ & & $\begin{array}{l}\text { Non- } \\
\text { inoculation } \\
(\mathrm{M} 1)\end{array}$ & $\begin{array}{l}\text { Inoculation } \\
\text { (M2) }\end{array}$ & \\
\hline 0 g plant $^{-1}$ & $30.23 c$ & $63.83 \mathrm{c}$ & $49.0 \mathrm{C}$ & $48.73 \mathrm{~d}$ & $17.49 \mathrm{e}$ & $33.1 \mathrm{D}$ & $41.11 \mathrm{f}$ & $15.64 \mathrm{~h}$ & $28.3 \mathrm{D}$ \\
\hline 27.17 g plant $^{-1}$ & $31.05 \mathrm{c}$ & $714.76 \mathrm{~b}$ & $362.7 \mathrm{~B}$ & $57.41 \mathrm{~d}$ & $417.50 \mathrm{~b}$ & $237.4 \mathrm{~B}$ & $45.01 \mathrm{f}$ & $117.33 b$ & $81.1 \mathrm{~A}$ \\
\hline $54.34 \mathrm{~g} \mathrm{plant}^{-1}$ & $38.67 \mathrm{c}$ & $846.82 \mathrm{a}$ & 442.7A & $42.48 \mathrm{~d}$ & $475.00 \mathrm{a}$ & $258.7 \mathrm{~A}$ & $37.56 \mathrm{f}$ & $132.81 \mathrm{a}$ & $85.1 \mathrm{~A}$ \\
\hline $81.52 \mathrm{~g} \mathrm{plant}^{-1}$ & $25.42 \mathrm{c}$ & $54.18 \mathrm{c}$ & $39.0 \mathrm{C}$ & $82.40 \mathrm{~d}$ & $280.00 \mathrm{c}$ & $181.2 \mathrm{C}$ & $23.48 \mathrm{~g}$ & $70.54 \mathrm{~d}$ & $47.0 \mathrm{C}$ \\
\hline $\begin{array}{l}108.69 \mathrm{~g} \\
\text { plant }^{-1}\end{array}$ & $52.93 \mathrm{c}$ & $77.99 \mathrm{c}$ & $65.4 \mathrm{C}$ & $79.32 \mathrm{~d}$ & $282.99 \mathrm{c}$ & $181.1 \mathrm{C}$ & $54.69 \mathrm{e}$ & $86.18 \mathrm{c}$ & $70.4 \mathrm{~B}$ \\
\hline Average $(\mathrm{F})$ & $35.66 \mathrm{~B}$ & $352.19 \mathrm{~A}$ & & $62.07 \mathrm{~B}$ & $294.59 \mathrm{~A}$ & & $40.37 \mathrm{~B}$ & $84.50 \mathrm{~A}$ & \\
\hline F-test ; F & & $* *$ & & & $* *$ & & & $* *$ & \\
\hline M & & $* *$ & & & $* *$ & & & $* *$ & \\
\hline $\mathrm{F} * \mathrm{M}$ & & $* *$ & & & $* *$ & & & $* *$ & \\
\hline C.V. $(\%)$ & & 21.28 & & & 10.36 & & & 12.05 & \\
\hline
\end{tabular}

Note. Number is average of 4 replications, followed by a letter. Different letter means there is a significant different at $99 \%$ confidence interval by LSD.

Table 5. Soil reaction $(\mathrm{pH})$ in the soil at flowering, fruit setting and harvesting stage of grape

\begin{tabular}{|c|c|c|c|c|c|c|c|c|c|}
\hline \multirow[b]{2}{*}{ Fertilizers (F) } & \multicolumn{2}{|c|}{ Flowering stage } & \multirow{2}{*}{$\begin{array}{c}\text { Average } \\
\text { (M) }\end{array}$} & \multicolumn{2}{|c|}{ Fruit setting stage } & \multirow{2}{*}{$\begin{array}{c}\text { Average } \\
\text { (M) }\end{array}$} & \multicolumn{2}{|c|}{ Harvesting stage } & \multirow{2}{*}{$\begin{array}{c}\text { Average } \\
\text { (M) }\end{array}$} \\
\hline & $\begin{array}{c}\text { Non- } \\
\text { inoculation } \\
\text { (M1) }\end{array}$ & $\begin{array}{l}\text { Inoculation } \\
\text { (M2) }\end{array}$ & & $\begin{array}{c}\text { Non- } \\
\text { Inoculation } \\
\text { (M1) }\end{array}$ & $\begin{array}{c}\text { Inoculation } \\
\text { (M2) }\end{array}$ & & $\begin{array}{c}\text { Non- } \\
\text { inoculation } \\
\text { (M1) }\end{array}$ & $\begin{array}{c}\text { Inoculation } \\
\text { (M2) }\end{array}$ & \\
\hline 0 g plant $^{-1}$ & $6.69 \mathrm{a}$ & $6.46 \mathrm{a}$ & $6.57 \mathrm{~A}$ & $6.80 \mathrm{bc}$ & $7.01 \mathrm{ab}$ & $6.90 \mathrm{~A}$ & $6.79 \mathrm{a}$ & $6.75 \mathrm{a}$ & $6.77 \mathrm{~A}$ \\
\hline 27.17 g plant $^{-1}$ & $6.75 \mathrm{a}$ & $6.66 \mathrm{a}$ & $6.71 \mathrm{~A}$ & $6.97 \mathrm{abc}$ & $6.46 \mathrm{~d}$ & $6.72 \mathrm{~B}$ & $6.89 \mathrm{a}$ & $6.56 \mathrm{~b}$ & $6.72 \mathrm{~A}$ \\
\hline $54.34 \mathrm{~g} \mathrm{plant}^{-1}$ & $6.67 \mathrm{a}$ & $5.57 \mathrm{~b}$ & $6.12 \mathrm{~B}$ & $7.11 \mathrm{a}$ & $5.75 \mathrm{e}$ & $6.43 \mathrm{C}$ & $6.87 \mathrm{a}$ & $5.76 \mathrm{c}$ & $6.31 \mathrm{~B}$ \\
\hline $81.52 \mathrm{~g} \mathrm{plant}^{-1}$ & $6.84 \mathrm{a}$ & $4.42 \mathrm{c}$ & $5.63 \mathrm{C}$ & $6.74 \mathrm{c}$ & $4.45 f$ & $5.59 \mathrm{E}$ & $6.69 \mathrm{ab}$ & $4.42 \mathrm{e}$ & $5.55 \mathrm{C}$ \\
\hline $\begin{array}{l}108.69 \mathrm{~g} \\
\text { plant }^{-1}\end{array}$ & $4.81 \mathrm{c}$ & $6.59 \mathrm{a}$ & $5.70 \mathrm{C}$ & $4.61 \mathrm{f}$ & $6.90 \mathrm{abc}$ & $5.76 \mathrm{D}$ & $4.78 \mathrm{~d}$ & $6.67 \mathrm{ab}$ & $5.72 \mathrm{C}$ \\
\hline Average $(\mathrm{F})$ & $6.35 \mathrm{~A}$ & 5.94B & & $6.44 \mathrm{~A}$ & $6.11 \mathrm{~B}$ & & $6.40 \mathrm{~A}$ & $6.03 \mathrm{~B}$ & \\
\hline F-test ; F & & $* *$ & & & $* *$ & & & $* *$ & \\
\hline M & & $* *$ & & & $* *$ & & & $* *$ & \\
\hline $\mathrm{F} * \mathrm{M}$ & & $* *$ & & & $* *$ & & & $* *$ & \\
\hline C.V. (\%) & & 3.47 & & & 1.63 & & & 12.45 & \\
\hline
\end{tabular}

Note. Number is average of 4 replications, followed by a letter. Different letter means there is a significant different at $99 \%$ confidence interval by LSD.

Table 6. The concentration of phosphorus (\%) in leaf at flowering and harvesting stage of grape

\begin{tabular}{|c|c|c|c|c|c|c|}
\hline \multirow[b]{2}{*}{ Fertilizers (F) } & \multicolumn{2}{|c|}{ Flowering stage } & \multirow{2}{*}{$\begin{array}{c}\text { Average } \\
\text { (M) }\end{array}$} & \multicolumn{2}{|c|}{ Harvesting stage } & \multirow[t]{2}{*}{ Average (M) } \\
\hline & $\begin{array}{c}\text { Non-inoculation } \\
\text { (M1) }\end{array}$ & $\begin{array}{l}\text { Inoculation } \\
\text { (M2) }\end{array}$ & & $\begin{array}{c}\text { Non-inoculation } \\
\text { (M1) }\end{array}$ & $\begin{array}{l}\text { Inoculation } \\
\text { (M2) }\end{array}$ & \\
\hline 0 g plant $^{-1}$ & $0.28 \mathrm{~h}$ & $0.42 \mathrm{c}$ & $0.34 \mathrm{C}$ & $0.25 \mathrm{~d}$ & $0.31 \mathrm{c}$ & $0.28 \mathrm{~B}$ \\
\hline 27.17 g plant $^{-1}$ & $0.30 \mathrm{~g}$ & $0.50 \mathrm{a}$ & $0.40 \mathrm{~A}$ & $0.24 \mathrm{~d}$ & $0.35 \mathrm{a}$ & $0.30 \mathrm{~A}$ \\
\hline $54.34 \mathrm{~g} \mathrm{plant}^{-1}$ & $0.35 \mathrm{e}$ & $0.39 d$ & $0.37 \mathrm{~B}$ & $0.26 \mathrm{~d}$ & $0.33 b$ & $0.30 \mathrm{~A}$ \\
\hline $81.52 \mathrm{~g} \mathrm{plant}^{-1}$ & $0.32 \mathrm{f}$ & $0.45 b$ & $0.38 \mathrm{~B}$ & $0.26 \mathrm{~d}$ & $0.32 b$ & $0.28 \mathrm{~B}$ \\
\hline $108.69 \mathrm{~g} \mathrm{plant}^{-1}$ & $0.32 \mathrm{f}$ & $0.39 \mathrm{~d}$ & $0.35 \mathrm{C}$ & $0.25 \mathrm{~d}$ & $0.30 \mathrm{c}$ & $0.28 \mathrm{~B}$ \\
\hline Average (F) & $0.31 \mathrm{~B}$ & $0.43 \mathrm{~A}$ & & $0.25 \mathrm{~B}$ & $0.32 \mathrm{~A}$ & \\
\hline F-test ; F & & $* *$ & & & $* *$ & \\
\hline M & & $* *$ & & & $* *$ & \\
\hline $\mathrm{F}^{*} \mathrm{M}$ & & $* *$ & & & $* *$ & \\
\hline C.V. (\%) & & 11.44 & & & 12.56 & \\
\hline
\end{tabular}

Note. Number is average of 4 replications, followed by a letter. Different letter means there is a significant different at $99 \%$ confidence interval by LSD. 
However, the increase $\mathrm{P}$ content in leaf of grapes may have been ability of the mycorrhizal fungi to extrametrical hyphae in the roots and ultimately help for absorption of water, available phosphorus and other nutrients for plant growth (Gosling et al., 2005).

\section{Conclusion}

The inoculation of mycorrhizal fungi increased spore number, root colonization density, phosphatases activity of mycorrhizal fungi, available $\mathrm{P}$ in soil and $\mathrm{P}$ in leaf compared with the non-inoculated. While, phosphate fertilizer at a rate $54.34 \mathrm{~g} \mathrm{plant}^{-1}$ increased spore number, root colonization density, phosphatases activity of mycorrhizal fungi, available $\mathrm{P}$ in soil and $\mathrm{P}$ in leaf. Mycorrhizal fungi combination with $54.34 \mathrm{~g} \mathrm{plant}^{-1}$ of phosphate fertilizer increased spore number, root colonization density, phosphatases activity and available $\mathrm{P}$ in soil.

\section{Acknowledgement}

We gratefully acknowledge the Graduate School at Kasetsart University for financial support and thank the agriculturist at Nakhonratchasrima Province for providing the supporting facilities and the location for the research conducted in this manuscript.

\section{References}

Aguilera-Gomez, L., Davies, F. T., Olalde-Portugal, Jr. V., Duray, S. A., \& Phavaphutanon, L. (1999). Influence of phosphorus and endomycorrhiza (Glomus intraradices) on gas exchange and plant growth of chili pepper (Capsicum annuum L. cv. San Luis). Photosynthetica, 36, 441-449. http://dx.doi.org/10.1023/A:1007032320951

Azcón, R., \& Barea, J. M. (1997). Mycorrhizal dependency of a representative plant species in Mediterranean shrublands (Lavandula spica L.) as a key factor to its use for revegetation strategies in desertifi cationthreatened areas. Appl. Soil Ecol., 7, 83-92. http://dx.doi.org/10.1016/S0929-1393(97)00013-9

Barker, A. V., \& Pilbeam, D. J. (2007). Handbook of plant nutrition. Taylor \& Francis Group, LLC, USA.

Brundrett, M., Melville, L., \& Peterson, L. (1994). Practical Methods in Mycorrhizal Research. Mycologue Publications. Ontario, Canada. $161 \mathrm{pp}$.

Das, K., Dang, R., Shivananda, T. N., \& Sekeroglu, N. (2007). Infl uence of bio-fertilizers on the biomass yield and nutrient content in Stevia rebaudiana Bert. grown in Indian subtropics. J. Med. Plant Res., 1, 5-8.

Gamalero, E., Trotta, A., Massa, N., Copetta, A., Martinotti, M. G., \& Berta, G. (2004). Impact of two fluorescent pseudomonads and an arbuscular mycorrhizal fungus on tomato plant growth, root architecture and $\mathrm{P}$ acquisition. Mycorrhiza, 14, 185-92. http://dx.doi.org/10.1007/s00572-003-0256-3

Giovanetti, M., \& Mosse, B. (1980). An evaluation of techniques for measuring vesicular arbuscular $\begin{array}{lllll}\text { mycorrhizal infection in } & \text { roots. } & \text { Phytol., } & \text { 84, }\end{array}$ http://dx.doi.org/10.1111/j.1469-8137.1980.tb04556.x

Gosling, P., Higge, A., Goodlass, G., \& Bending, G. D. (2005). Arbuscular mycorrhizal fungi and organic farming. Agric. Ecosyst. Environ., 133, 17-35.

Grant, C. A., Flaten, D. N., Tomasiewicz, D. J., \& Sheppard, S. C. (2001). The importance of early season $\quad$ P nutrition. Can. J. Plant Sci., 81, 211-224. http://dx.doi.org/10.4141/P00-093

Irene, M. C., \& Thomas, W. K. (2006). Mycorrhizas and tropical soil fertility. Agric. Ecosyst. Environ., 116, $72-$ 84. http://dx.doi.org/10.1016/j.agee.2006.03.011

Kumar, K. V. C., Chandrashekhar, K. R., \& Lakshmipathy, R. (2008). Variation in arbuscular mycorrhizal fungi and phosphatase activity associated with Sida cardifolia in Karnataka. World J. Agric. Sci., 4, 770-774.

Linderman, R. G., \& Davis, E. A. (2004). Evaluation of commercial inorganic and organic fertilizer effect on arbuscular mycorrhizae formed by Glomus intraradices. Hort. Tech., 14, 196-202.

Mala, T., Phuengsaeng, W., Phumpetch, J., \& Jiamjirachat, M. (1998). The Effectiveness Evaluation of VAM Fungi on Enhancement of Plant Growth and Phosphorus Uptake of Maize and Soybean. Final Report of Ksaetsart University Deployment and Research Institute. Department of Soil Science, Faculty of Agriculture, Kasetsart University, Bangkok. 18 p. (in Thai, English abstract)

Plenchette, C., Clermont-Dauphin, C., Meynard, J. M., \& Fortin, J. A. (2005). Managing arbuscular mycorrhizal fungi in cropping systems. Can. J. Plant Sci., 85, 31-40. http://dx.doi.org/10.4141/P03-159

Quilambo, O. A. (2003). The vesicular-arbuscular mycorrhizal symbiosis. African J. Biotechnol, 2, 539-546. 
Sumana, D. A. (1998). Influence of VA Mycorrhizal Fungi in Nitrogen Fixing and Mycorrhization Helper Bacteria on Growth of Neem (Azadirachta indica A. Juss). Ph.D. Thesis, UAS. Bangalore, India.

Tabatabai, M. A., \& Bremner, J. M. (1969). Use of p-nitrophenylphosphate for assay of soilphosphatase activity. Soil Biol Biochem, 1, 301-307. http://dx.doi.org/10.1016/0038-0717(69)90012-1

Tadano, T., Ozawa, K., Sakai, H., Osaki, M., \& Mutsui, H. (1993). Secretion of acid phosphatase by the roots of crop plants under phosphorus deficient conditions and some properties of the enzyme secreted by lupin roots. Plant Soil., 155, 95-98. http://dx.doi.org/10.1007/BF00024992

Tassanee, A., Chanjaroensuk, C., \& Jintakanon, S. (1989). Soil and Plant Analysis: Practice and Labolatory Manual. Department of Soil Science, Faculty of Agriculture, Kasetsart University. 171 p. (in Thai)

Tiessen, H. (1995). Phosphorus in the Global Environment. Transfers, Cycles and Management. SCOPE 54. John Wiley and Sons, New York.

\section{Copyrights}

Copyright for this article is retained by the author(s), with first publication rights granted to the journal.

This is an open-access article distributed under the terms and conditions of the Creative Commons Attribution license (http://creativecommons.org/licenses/by/3.0/). 